\title{
SISTEM PENGELUARAN BIAYA OPERASIONAL PADA PT BANK BTN (PERSERO) KANTOR WILAYAH V MAKASSAR
}

\author{
Ahmad Firdaus \\ dauz4646@gmail.com \\ Politeknik Informatika Nasional
}

\begin{abstract}
The research aims to find out the Operating Cost Expenditure System at PT Bank BTN (persero) Regional Office V Makassar. The research used descriptive qualitative, where the researcher described the results of observations and analyzed the data. The writing research conducted in March 2019 to May 2019. After analyzing and discussing the problem, the researcher concluded that the Operating Expenditure System at PT Bank BTN (Persero) Makassar V Regional Office arranged in the Order to Pay PT Bank BTN (persero) V Regional Office Makassar. Operating system expenditure on PT Bank BTN (persero) Makassar V Regional Office is for the procurement of goods and services, then price comparisons will be made based on third party offerings, then based on what offer will be agreed in the form of monthly, quarterly, semester or annual. Most of the PKS (cooperation agreements) are in monthly form so that the third partner will collect every month and will be paid by the officer.
\end{abstract}

Keywords: Systems, expenditures, Operating Costs.

\begin{abstract}
Abstrak
Jenis penelitian yang digunakan adalah deskriptif kualitatif, yaitu penulis menggambarkan hasil observasi dan menganalisa data-data yang diperoleh dilapangan mengenai suatu proses langkah kerja. Penulisan tugas akhir ini merupakan hasil penelitian yang dilakukan pada bulan Maret 2019 sampai dengan Mei 2019. Setelah melakukan analisa dan pembahasan masalah, penulis memperoleh kesimpulan Sistem Pengeluaran Biaya Operasional pada PT Bank BTN (persero) Kantor Wilayah V Makassar diatur dalam Surat Perintah Membayar PT Bank BTN (persero) Kantor Wilayah V Makassar. Sistem penegeluaran biaya operasional pada PT Bank BTN (persero) Kantor Wilayah V Makassar adalah untuk pengadaan barang dan jasa maka akan dilakukan perbandingan harga berdasarkan penawaran dari pihak ketiga, selanjutnya berdasarkan penawaran tersebut akan disepakati dalam bentuk apa missal bulanan, triwulanan, semesteran atau tahunan. Sebagian besar perjanjian Kerja Sama (PKS) dalam bentuk bulanan sehingga rekanan pihk ketiga akan menagih setiap bulan dan akan dibayarkan oleh petugas.
\end{abstract}

Kata kunci: Sistem, pengeluaran, Biaya Operasional. 


\section{PENDAHULUAN}

Perbankan merupakan salah satu lembaga keuangan, alat penggerak pertumbuhan dan penggerak ekonomi yang fungsinya tidak dapat dipisahkan dari pembangunan. Kegiatan perkreditan dan berbagai jasa yang diberikan oleh bank ini membantu masyarakat mengatasi kekurangan modal dalam mengatasi kesenjangan sosial dan membantu dalam mengembangkan suatu usaha sehingga meningkatkan produktivitas, kesejahtraan masyarakat,dan meningkatkan daya saing.

Pemberian kredit merupakan aktivitas paling pokok dari perbankan, hal tersebut merupakan salah satu fungsi intermediasi bank yaitu menghimpun dana dari masyarakat kemudian menyalurkan kembali dana kepada masyarakat yang membutuhkan untuk segala kebutuhan primer maupun sekunder. Dengan maksud mendidik masyarakat agar gemar menabung, Pemerintah Hindia Belanda melalui Koninklijk Besluit No. 27 Tanggal 16 Oktober 1897 mendirikan Postpaar Bank. Yang kemudian terus hidup dan berkembang serta tercatat hingga tahun 1939 telah memiliki 4 (empat) cabang yaitu Jakarta, Medan, Surabaya dan Makassar.

Pada tahun 1940 kegiatanya terganggu, sebagai akibat penyerbuan Jerman atas Netherland yang mengakibatkan penarikan tabungan besar-besaran dalam waktu yang relatif singkat (rush). Namun demikian keadaan keuanganPostpaar Bank pulih kembali pada tahun 1941. Tahun 1942 Hindia Belanda menyerah tanpa syarat kepada Pemerintah Jepang. Jepang membekukan kegiatanPostpaar Bank dan mendirikan Tyokin Kyoku sebuah bank yang bertujuan untuk menarik dana masyarakat melalui tabungan. Usaha pemerintah Jepang ini tidak sukses karena dilakukan dengan paksaan Tyokin Kyoku hanya mendirikan satu cabang yaitu cabang Yogyakarta.

Proklamasi kemerdekaan R.I. 17 Agustus 1945 telah memberikan inspirasi kepada Bapak Darmosoetanto untuk memprakarsai Tyokin Kyoku dari Pemerintah Jepang ke Pemerintah R.I. dan terjadilah penggantian nama menjadi KANTOR TABUNGAN POS. Bapak Darmosoetanto ditetapkan oleh Pemerintah R.I. menjadi Direktur yang pertama. Tugas pertama KANTOR TABUNGAN POS adalah melakukan penukaran uang Jepang dengan Oeang Republik Indonesia (ORI) tetapi kegiatan KANTOR TABUNGAN POS tidak berumur panjang. Karena agresi Belanda (Desember 1946) mengakibatkan didudukinya semua kantor, termasuk kantor cabang dari KANTOR TABUNGAN POS hingga tahun 1949. Saat KANTOR TABUNGAN POS dibuka kembali (1949). Nama KANTOR TABUNGAN POS diganti menjadi BANK TABUNGAN R.I. Sejak kelahiranya dan sampai berubah nama BANK TABUNGAN POS R.I. lembaga ini bernaung di bawah Kementrian Perhubungan.

Banyak kejadian bernilai sejarah sejak tahun 1950 tetapi yang substantif bagi sejarah BTN adalah dikeluarkanya Undang-Undang Darurat No.9 th. 1950 tanggal 9 Febuari 1950 yang mengubah nama "POSTPAARBANKIN INDONESIA" berdasarkan staatsblat No. 295 tahun 1941 menjadi BANK TABUNGAN POS dan memindahkan induk kementrian dari Kementrian Perhubungan ke Kementrian Keuangan di bawah Menteri Urusan Bank Sentral. Walaupun dengan UndangUndang Darurat tersebut dikukuhkan 
dengan UU No.36 tahun 1953 tanggal 18 Desember 1953. Perubahan nama dari BANK TABUNGAN POS menjadi BANK TABUNGAN NEGARA didasarkan pada PERPU No.4 tahun 1963 tanggal 22 Juni 1963 yang kemudian dikuatkan dengan Undang - Undang No. 2 tahun 1964 tanggal 25 Mei 1964.

Penegasan status BANK TABUNGAN NEGARA sebagai bank milik negara ditetapkan dengan Undang - Undang No.20 tahun 1968 tanggal 19-12-1968 yang sebelumnya (Sejak Tahun 1964) BANK TABUNGAN NEGARA menjadi BNI unit V. Jika tugas utama saat pendiriaan Postspaarbank (1897) sampai dengan BANK TABUNGAN NEGARA (1968) adalah bergerak dalam lingkup penghimpunan dana masyarakat melalui tabungan, maka sejak tahun 1974 BANK TABUNGAN NEGARA ditambah tugasnya yaitu memberikan pelayanan KPR dan untuk pertama kalinya penyaluran KPR terjadi pada tanggal 10 Desember 1976.

Sebab itulah tanggal 10 Desember diperingati sebagai hari KPR bagi BTN. Bentuk hukum BTN mengalami perubahan lagi pada tahun 1992, yaitu dengan dikeluarkanya PP No. 24 tahun 1992 tanggal 29 April 1992 yang merupakan pelaksanaan dan UU No.7 tahun 1992 bentuk hukum BTN, berubah menjadi Perusahaan Perseroan. Sejak itu nama BTN menjadi PT. BANK TABUNGAN NEGARA (PERSERO) dengan call name Bank BTN. Berdasarkan kajian consultan independent, Price Waterhouse Coopers. Pemerintah melalui Menteri BUMN dalam surat Nomor S544/MMBU/ 2002 tanggal 21 Agustus 2002 memutuskan Bank BTN sebagai Bank Umum dengan fokus bisnis pembiayaan perumahan tanpa subsidi.

Dari tahun ke tahun, bank BTN berupaya untuk melaksanakan diversifikasi sarana dan prasarana. Terutama dengan cara pembukaan Kantor Cabang dan Kator Cabang Pembantu baru yang tersebar di seluruh wilayah Indonesia. Salah satunya dengan pembukaan Kantor Cabang SOLO. Kemudian ditingkatkan lagi dengan pembukaan kantor Cabang Pembantu di wilayah Karesidenan Surakarta yaitu Kantor Cabang Pembantu (KCP) Mojosongo, KCP Palur, KCP Klaten, KCP Universitas Sebelas Maret, dan KCP Sukoharjo.

Berdasarkan Undang-Undang Republik Indonesia No. 10 Tahun 1998 Tanggal, 10 Nopember 1998 tentang perubahan atas Undang-Undang nomor 7 tahun 1992 tentang Perbankan menyatakan bahwa Bank adalah badan usaha yang menghimpun dana dari masyarakat dalam bentuk simpanan dan menyalurkannya kepada masyarakat dalam bentuk kredit dan atau bentukbentuk lainnya dalam rangka meningkatkan taraf hidup rakyat banyak.

Salah satu kelompok bank yang turut berperan dalam menggerakkan perekonomian adalah Bank Tabungan Negara (BTN). Bank Tabungan Negara (BTN) sebagai pemegang keuangan daerah, yang telah diatur di dalam undang-undang No. 13 tahun 1962 tentang asas-asas Ketentuan Bank Tabungan Negara (BTN), berkerja sebagai pengembangan perekonomian daerah dan menggerakkan pembangunan ekonomi daerah untuk meningkatkan taraf kehidupan masyarakat serta menyediakan pembiayaan keuangan pembangunan di daerah, menghimpun dana serta melaksanakan dan menyimpan kas daerah (pemegang/penyimpanan kas daerah) selain menjalankan kegiatan bisnis perbankan. 
Penerapan sistem akuntansi dalam dunia perbankan sangatlah penting salah satunya adalah penerapan sistem pengeluaran kas yang dapat mengoptimalkan biaya operasional yang dikeluarkan, mengingat kas adalah aktiva yang mudah berubah dibandingkan dengan aktiva lain, sehingga kas merupakan alat pembayaran yang bebas dan selalu siap sedia untuk digunakan.

Dalam prakteknya tidak semua pengeluaran uang dapat dilakukan dengan cek. Pengeluaran dalam jumlah kecil seperti biaya bahan bakar, biaya snack pegawai dan biaya kebutuhan dapur biasanya tidak menggunakan cek karena tidak praktis. Untuk mengatasi hal demikian maka perusahaan perlu menyisihkan sejumlah uang tertentu yang disebut dana sandi anggaran yang telah ditetapkan diawal tahun yang dipegang oleh seorang yang ditunjuk sebagai GA staff. Jenis dan jumlah pengeluaran uang tertentu yang telah ditetapkan dapat dilakukan melalui dana sandi anggaran operasional. Karena fungsinya yang demikian penting bagi perusahaan dana sandi anggaran operasional ini sudah merupakan kebutuhan yang mutlak harus ada.

Dapat dibayangkan betapa tidak efektifnya apabila dana sandi anggaran Operasional ini tidak disediakan anggarannya. Walaupun dana dana sandi anggaran Operasional merupakan dana yang sedikit tetapi dana sandi anggaran Operasional ini juga perlu dikelola dengan baik mengingat dana sandi anggaran Operasional digunakan dalam transaksi yang terjadi setiap hari. Jumlah besarnya dana sandi anggaran Operasional masingmasing perusahaan berbeda-beda sesuai dengan kebijakan internal perusahaan. Dengan adanya dana sandi anggaran Operasional, kebutuhan sehari-hari dari perusahaan yang bersangkutan akan terpenuhi. Contohnya di PT Bank BTN kantor Wilayah V Makassar, dana sandi anggaran Operasional dikelola oleh pegawai yang diawasi oleh procurement dan GA staff, yaitu berupa data dalam bentuk kasbon yang nantinya akan dicairkan di teller untuk memenuhi kebutuhan Bank.

Berdasarkan uraian diatas, penulis tertarik untuk mengambil judul yaitu: "Sistem Pengeluaran Biaya Operasional Pada PT Bank BTN (persero) Tbk Kantor Wilayah V Makassar"

\section{TINJAUAN PUSTAKA \\ a. Pengertian Sistem}

Sistem berasal dari bahasa latin (systema) dan bahasa yunani (austema). Artinya suatu kesatuan kompenen atau elemen yang dihubungkan bersama untuk memudahkan aliran informasi, materi atau energi. Istilah ini sering di gunakan untuk menggambarkan suatu sentitas yang berinteraksi, sering kali menggunakan suatu modal matematika.

Secara garis besar sistem merupakan suatu kumpulan komponen danelemen yang saling terintegrasi, komponen yang terorganisir dan bekerja sama dalam mewujudkan suatu tujuan tertentu. Adapun pengertian sistem menurut pendapat beberapa ahli adalah sebagai berikut. Menurut (Mulyadi,2016,hal.2), menjelaskan bahwa:

"sistem adalah sekelompok yang erat berhubungan satu dengan yang lainnya,yang berfungsi bersama-sama untuk mencapai tujuan tertentu dan diciptakan untuk untuk menangani sesuatu yang beulang kali atau yang rutin terjadi.

Sedangkan (sujarweni,2016,hal.1) menjelaskan bahwa:"sistem adalah 
kumpulan elemen-elemen yang saling berkaitan sangat bekerjasama dalam melakukan kegiatan untuk mencapai tujuan tertentu".Sementara itu. Menurut Sutanto dalam Djahir dan Pratita (2015,hal.6) mengemukakan bahwa:"sistem adalah kumpulan/grup dari subsistem/bagian/komponen apapun, baik fisik ataupun nonfisik yang saling berhubungan satu sama lain dan bekerja sama secara harmonis untuk mencapai satu tujuan tertentu". Selain itu menurut Hutahaean (2015,hal.2) mengemukakan bahwa :"sistem adalah suatu jaringan kerja dari prosedurprosedur yang saling berhubungan, berkumpul bersama-sama untuk melakukan kegiatan atau untuk melakukan sasaran yang tertentu".

Dari beberapa uraian diatas, dapat disimpulkan bahwa sistem merupakan kumpulan dari unsur atau bagian yang berhubungan dan bekerjasama untuk mencapai tujuan tertentu yang diinginkan. Unsur atau bagian tersebut bisa merupakan prosedur-prosedur atau subsistem yang terkumpul dan diatur sedemikian rupa untuk mencapai suatu sistem yang diinginkan. Sistem merupakan suatu kesatuan yang memiliki tujuan bersama dan memiliki bagianbagian yang saling berinteraksi satu sama lain.

Sebuah sistem harus memiliki dua kegiatan:

a. Adanya masukan (Input) yang merupakan sebagai sumber tenaga untuk dapat beroperasinya sebuah sistem

b. Adanya kegiatan operasional atau proses yang mengubah masukan menjadi keluaran (output) berupa hasil operasi (tujuan, sasaran, target, pengoperasian suatu sisitem).
Berikut ini karakteristik sistem menurut (Mulyadi, 2016 ,hal.2) secara umum sebagai berikut:

a. Setiap sistem unsur-unsur. Unsur terdiri dari subsistem yang kecil, yang terdiri pula dari kelompok unsur yang berbentuk subsistem tersebut.

b. Unsur-unsur tersebut merupakan bagian terpadu sistem yang bersangkutan antara unsur-unsur sistem mempunyai hubungan erat dan sifatnya kerjasama.

c. Unsur sistem tersebut bekerjasama untuk mencapai tujuan sistem, setiap sistem mempunyai tujuan tertentu.

d. Suatu sistem bagian dari sistem lain yang lebih besar.

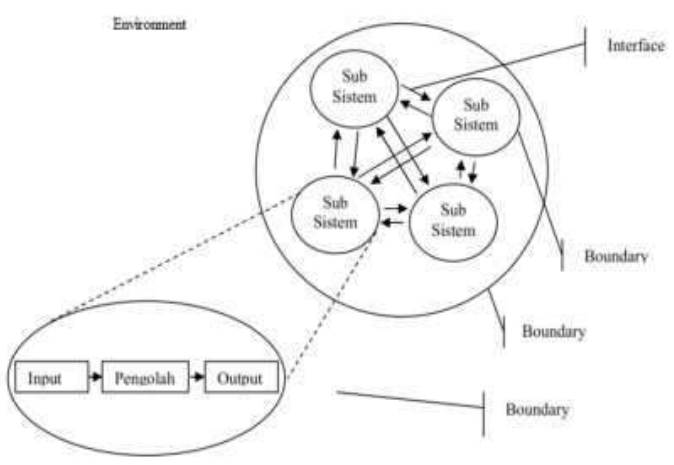

Sumber: Hutahaean (2015:5)

Tahap-tahap pengembangan sistem menurut (Sujarweni 2015,p.21) dilakukan beberapa langkah sebagai berikut:

a. Analisis Sistem

Analisis sistem dilakukan oleh seseorang analisis dengan cara mensurveilangsung di perusahaan, apa saja yang diperlukan oleh karyawan untuk melaksanakan pekerjaannya.

b. Desain sistem

Desain adalah penerjemah kebutuhan pemakai informasi dalam bentuk rancangan sistem yang diajukan kepada pemakai informasi untuk dipelajari dan dipertimbangkan. 


\section{c. Implementasi sistem}

Implementasi sistem adalah penerapan sisytem yang akan dilakukan berdasarkan hasil analisis sistem dan desain sistem yang telah dilakukan olehanalisis.setelah sistem disetujui maka program yang telah dibuaatsiap untuk dioprerasikan. Pada tahap ini analisis sistem membuat dokumen yang disebut laporan final implementasi sistem.

\section{b. Pengertian Pengeluran}

Menurut Kamus Besar Bahasa Indonesia (KBBI) makna atau definisi pengeluaran adalah :Pengeluaran adalah Expenditure yaitu pembayaran yang dilakukan saat ini untuk kewajiban pada masa akan datang dalam rangka memperoleh beberapa keuntungan (untung), jika dilakukan untuk meningkatkan aktifa tetap, pengeluaran itu disebut pengeluaran modal, jika dilakukan untuk biaya operasi, pengeluaran itu disebut pengeluaran operasional,biaya tunai tersebut untuk mendapatkan barang,jasa,atau hasil usaha.

\section{c. Pengertian Biaya operasional}

Untuk menjalankan suatu usaha diperlukan sumber daya yang harus dikorbankan sebagai nilai pengganti untuk memperoleh keuntungan. Sumber daya ini pada umumnya di nilai dengan satuan uang. Dimana sumber daya yang dipergunakan seringkali disebut dengan biaya. Pengertian biaya menurut Mulyadi adalah Biaya adalah pengorbanan sumber ekonomi yang diukur dalam satuan uang, yang telah terjadi atau yang kemungkinan akan terjadi untuk tujuan tertentu.( Mulyadi, Akuntansi Biaya, "Yogyakarta: UPP STIM YKPM, 2009.”, hal. 8).

Terdapat empat unsur pokok dalam pengertian diatas, yaitu :
1. Biaya merupakan pengorbanan sumber ekonomi.

2. Diukur dalam satuan uang.

3. Yang telah terjadi atau yang secara potensial akan terjadi.

4. Pengorbanan tersebut untuk tujuan tertentu.

Dalam akuntansi, biaya diklarifikasikan dengan berbagai cara, umumnya pengklasifikasian atas dasar tujuan yang hendak dicapai dengan pengklasifikasian tersebut. Menurut Mulyadi biaya dapat diklasifikasikan sebagai berikut (Ibid, hal. 134).

1. Objek pengeluaran Dalam penggolongan objek pengeluaran ini merupakan dasar penggolongan biaya, misalnya nama objek pengeluaran "depresiasi mesin", maka semua objek pengeluaran yang berhubungan dengan depresiasi mesin disebut "biaya depresiasi mesin".

2. Fungsi pokok dalam perusahaan

a. Biaya produksi, merupakan biaya yang terjadi untuk mengolah bahan baku menjadi produk jadi yang siap jual.

b. Biaya pemasaran, merupakan biaya-biaya yang terjadi untuk melaksanakan kegiatan pemasaran produk.

c. Biaya administrasi, merupakan biaya untuk mengkoordinasi kegiatan produksi dan pemasaran produk.

3. Hubungan biaya dengan sesuatu yang dibiayai

a. Biaya langsung adalah biaya yang terjadi dimana penyebab satusatunya adalah karena adanya sesuatu yang dibiayai.

b. Biaya tidak langsung adalah biaya yang terjadinya tidak hanya disebabkan oleh sesuatu yang dibiayai. 
4. Perilaku biaya dalam hubungannya dengan perubahan volume kegiatan

a. Biaya variabel adalah biaya yang jumlah totalnya berubah.Sebanding dengan perubahan volume kegiatan.

b. Biaya semi variabel adalah biaya yang berubah tidak sebanding dengan perubahan volume kegiatan.

c. Biaya tetap adalah biaya yang jumlah totalnya tetap dalam kisaran volume kegiatan tertentu.

5. Jangka waktu manfaatnya

a. Pengeluaran modal (capital expenditure) adalah biaya yang mempunyai manfaat lebih dari satu periode akuntansi. Pada saat terjadi dibebankan sebagai harga pokok aktiva dan dibebankan dalam tahun pelaksanaannya.

b. Pengeluaran pendapatan (revenue expense) adalah biaya yang hanya mempunyai manfaat dalam periode akuntansi untuk terjadinya pengeluaran tersebut. Pada saat terjadinya pengeluaran pendapatan ini dibebankan sebagai biaya yang diperoleh dari pengeluaran biaya.(1 Mulyadi, Akuntansi Biaya, "Yogyakarta: UPP STIM YKPM, 2009.", hal. 8 / 2 Ibid, hal. 134)

\section{Biaya Operasional}

a. Pengertian biaya operasional

Pengertian biaya operasional yang dikemukakan oleh Rudianto adalah "biaya yang berkaitan dengan operasi perusahaan di luar biaya produksi". Sedangkan menurut Jusuf adalah sebagai berikut: "Biaya operasional atau biaya operasi adalah biaya-biaya yang tidak berhubungan langsung dengan produk perusahaan tetapi berkaitan dengan aktivitas operasional perusahaan seharihari".(Rudianto, Akuntansi Manajemen,
(Jakarta: Grasindo, 2006). Secara umum, biaya operasional diartikan sebagai biaya yang terjadi dalam kaitannya dengan operasi yang dilakukan perusahaan dan diukur dalam satuan uang. Dimana biaya operasi sering disebut juga sebagai operational cost atau biaya usaha ( Jopie Jusuf, Analisis Kredit, "Yogyakarta: Penerbit ANDI, 2008", hal. 33)

Yang termasuk beban operasional adalah semua jenis biaya yang berkaitan langsung dengan kegiatan usaha bank. Beban operasional terdapat dalam laporan laba rugi yang diperoleh dengan menjumlahkan biaya bagi hasil, biaya tenaga kerja, biaya umum administrasi, biaya penyusutan dan penyisihan aktiva produktif, biaya sewa gedung dan inventaris, dan sebagainya (Ibid, hal. 111) b. Tujuan Biaya Operasional

Adapun maksud dari semua biayabiaya ini dijalankan oleh pihak perusahaan, karena biaya ini mempunyai hubungan langsung dari kegiatan utama perusaahan. Menurut Sofyan Assauri,( Manajemen Produksi dan Operasi, "Jakarta: LPEE Universitas Indonesia, 1999", hal. 21-22 menjelaskan bahwa tujuan biaya operasi adalah:

1) Mengkoordinasikan dan mengendalikan arus masukan (input) dan keluaran (output), serta mengelola penggunaan sumber - sumber daya yang dimiliki agar kegiatan dan fungsi operasional dapat lebih efektif.

2) Untuk mengambil keputusan, akuntansi biaya menyediakan informasi biaya masa yang akan datang (future cost) karena pengambilan keputusan berhubungan dengan masa depan. Informasi biaya masa yang akan datang tersebut jelas tidak diperoleh dari catatan karena memang tidak dicatat, melainkan diperoleh dari hasil peramalan. Proses 
pengambilan keputusan khusus ini sebagian besar merupakan tugas manajemen perusahaan dengan memanfaatkan informasi biaya tersebut.

3) Digunakan sebagai pegangan atau pedoman bagi seorang manajer di dalam melakukan kegiatan-kegiatan perusahaan yang telah direncanakan perusahaan.

Agar mampu menghadapi persaingan yang semakin ketat, tuntutan konsumen yang meningkat dan pesatnya kemajuan teknologi informasi, maka pengelolaan bank secara efisien merupakan faktor penting untuk dapat terus bertahan. Efisiensi adalah "melakukan sesuatu secara tepat (do the things right)". Efisiensi didefinisikan sebagai hubungan antara input dan output yang dihasilkan dengan sumberdaya yang dipakai untuk melakukan aktivitas operasional. Bank dikategorikan efisien tergantung dari cara manajemen memproses input menjadi output.(Benyamin Molan, Glosarium Prentice Hall Untuk Manajemen Dan Pemasaran, "Jakarta: Prenhallindo, 2002", hal. 123).

Lembaga yang dalam kegiatan usahanya tidak efisien akan mengakhibatkan ketidakmampuan bersaing dalam mengerahkan dana masyarakat maupun dalam menyalurkan dana tersebut kepada masyarakat yang membutuhkan sebagai modal usaha. Efisiensi pada perbankan terutama efisiensi biaya akan menghasilkan tingkat keuntungan yang optimal, menambahkan jumlah dana yang disalurkan, biaya lebih kompetitif, peningkatan pelayanan kepada nasabah, keamanan dan kesehatan perbankan yang meningkat.

Salah satu alat yang digunakan untuk mengukur efisiensi perbankan adalah rasio BOPO. Rasio BOPO adalah perbandingan antara biaya operasional dengan pendapatan operasional. BOPO digunakan untuk mengukur tingkat efisiensi dan kemampuan bank dalam melakukan kegiatan operasinya.(Lukman Dendawijaya, Manajemen Perbankan, “Bogor: Ghalia Indonesia, 2005”, hal. 119)

BOPO $=\underline{\text { Beban Operasional }} \times 100 \%$

Pendapatan operasional Rasio BOPO juga memberikan gambaran mengenai:

a. Kemampuan manajemen perbankan dalam mengelola sumber daya (aktiva) yang ada untuk menghasilkan keuntungan optimal. Semakin tinggi efisiensi operasional bank dan menghasilkan aktiva untuk menghasilkan laba.

b. Kemampuan bank dalam hal pengendalian biaya. Semakin rendah BOPO berarti semakin efisien bank tersebut dalam mengembalikan biaya operasionalya. Sebaliknya tingginya BOPO mengindikasikan ketidakmampuan bank dalam mengatur dan mengendalikan biaya.

c. Kemampuan bank dalam menghasilkan profitabilitas. BOPO yang rendah mencerminkan tingginya kemampuan bank dalam menekan biaya operasional sehingga mampu mendorong naiknya profitabilitas. Sebaliknya, tingginya BOPO berarti tinggi pula beban yang ditanggung bank dan berimbas negative terhadap laba yang didapat.

d. Kemampuan bank dalam meminimalkan risiko operasional. Risiko operasional berasal dari kerugian operasional bila terjadi penurunan keuntungan yang dipengaruhi oleh struktur biaya operasional bank dan kemungkinan 
yang terjadinya kegagalan atas jasajasa dan produk-produk yang ditawarkan oleh bank. Rendahnya BOPO menunjukkan tingginya kemampuan bank dalam memimalkan risiko pembiayaan.

\section{c. Kerangka Pikir}

d.

Gambar 2.1 Kerangka Pikir

PT Bank BTN (Persero) merupakan perusahaan yang bergerak dalam lembaga keuangan perbankan dimana dalam menjalankan aktivitas perusahaan perlu memperhatikan sistem-sistem yang digunakan dalam perusahaan. Biaya merupakan komponen penting dalam kelancaran jalannya kegiatan operasional perusahaan. Untuk itu perusahaan perlu memperhatikan sistem Pengeluaran Biaya Operasional. Dalam Sistem Pengeluaran Biaya Operasional perlu diperhatikan proses penarikan dan pemberian Biaya Operasional. Sedangkan dalam Pengeluaran Biaya Operasional perlu memperhatikan proses perencanaan, pelaksanaan dan pengawasan.

\section{METODE PENELITIAN}

\section{a. Teknik Pengumpulan Data}

Dalam pengumpulan data ini selain peneliti melakukan pengamatan, peneliti juga menggunakan metode pengumpulan data yang lain sebagai berikut:

1. Studi Kepustakaan (Library Research)

Studi kepustakaan digunakan untuk mengumpulkan data sekunder. Landasan teori dan informasi yang berkaitan dengan penelitian ini. Studi dilakukan antara lain dengan mengumpulkan data yang bersumber dari literatur-literatur, bahan kuliah, dan hasil penelitian lainnya yang ada hubungannya dengan objek penelitian. Hal ini dilakukan untuk mendapatkan tambahan pengetahuan mengenai masalah yang sedang dibahas.

2. Studi Lapangan (Field Research)

Dalam penelitian ini penulis mengumpulkan data yang diperlukan dengan cara melakukan pengamatan langsung pada perusahaan yang bersangkutan, baik melalui observasi, wawancara dan dokumentasi. Penelitian Lapangan dilakukan dengan cara:

a. Observasi

Observasi merupakan suatu teknik atau cara pengumpulan data dengan jalan mengadakan pengamatan terhadap kegiatan yang sedang berlangsung. Adapun jenis observasi yang peneliti gunakan untuk mendapatkan data yang diperlukan guna mengetahui tujuan penelitian ini adalah observasi aktifitas pengelolaan kas kecil.

b. Wawancara

Wawancara adalah percakapan dengan maksud tertentu. Percakapan itu dilakukan oleh dua pihak, yaitu pewawancara (interviewer) yang mengajukan pertanyaan dan terwawancara (interviewee) yang memberikan jawaban atas pertanyaan itu. Dalam penelitian ini, peneliti 
menggunakan metode wawancara dalam bentuk wawancara bebas terpimpin yaitu dalam melaksanakan wawancara peneliti membawa pedoman yang hanya merupakan garis besar tentang hal-hal yang akan ditanyakan yang selanjutnya pertanyaan tersebut diperdalam.

c. Dokumentasi

Dokumentasi merupakan teknik pengumpulan data dengan cara memanfaatkan dokumen (bahan atau gambar-gambar penting). Adapun dokumen-dokumen yang dimaksud adalah berupa data-data yang diperlukan dalam penelitian

\section{b. Teknik Analisis Data}

Teknik analisis data yang digunakan adalah Deskriptif Kualitatif. Deskripsi kualitatif adalah suatu pemecahan masalah atau klasifikasi dengan cara pengumpulan data-data berdasarkan fakta yang ada sehingga dapat untuk dianalisis. Dalam hal ini penulis menggambarkan tentang Sistem Pengeluaran Biaya Operasional Pada PT Bank BTN (persero) Tbk Kantor Wilayah V Makassar.

\section{HASIL DAN PEMBAHASAN}

a. Hasil Penelitian

1. Sistem penegeluaran biaya operasional

Sistem penegeluaran biaya operasional pada PT Bank BTN (persero) Kantor Wilayah V Makassar adalah untuk pengadaan barang dan jasa maka akan dilakukan perbandingan harga berdasarkan penawaran daripihak ketiga, selanjutnya berdasarkan penawaran tersebut akan disepakati dalam bentuk apa misal bulanan, triwulanan, semesteran atau tahunan. Sebagian besar (Perjanjian Kerja Sama )PKS dalam bentuk bulanan sehingga rekanan pihk ketiga akan menagih setiap bulan dan akan dibayarkan oleh petugas.

Secara umum jenis pengeluaran biaya operasional pada PT Bank BTN (persero) Kantor Wilayah V Makassar tebagi menjadi 2 yaitu :

1. Pengadaan Barang, Sifatnya terbagi menjadi :

- Pembelian misalnya melakukan pembelian ATK

- Sewa misalnya computer

2. Pengadaan Jasa ,sifatnya terbagi menjadi :

- Keamanan

- Kebersihan

- Driver

Bagian yang terkait dalam pengeluaran biaya operasional yaitu:

1. Procurement dan GA Staff bertanggung jawab atas seluruh transaksi terkait biaya operasional

2. Operation unit head bertanggung jawab sebagai approval/persetujuan segala transaksi terkait biaya operasional

3. DRM Support bertanggung jawab sebagai otorisator untuk segala transaksi biaya operasional.

Dokumen yang digunakan untuk transaksi pengeluaran biaya operasional yaitu :

1. Form SPM atau surat perintah membayar yang teterah nominal dan tujuan pembayaran serta ditanda tangani oleh approval dan otorisator.

2. Bukti pendukung seperti memo, surat perjanjian kerja sama (PKS) tagihan dari pihak ketiga dll.

\section{Sistem Penarikan dan pemberian biaya operasional}

Penarikan biaya operasioal yaitu setiap biaya operasional memiliki posnya masing-masing yang telah ditentukan anggaran anggarannya sejak awal 
tahun,sebagai contohnya pos pengelolaan tenaga outsourching, pos tersebut akan bekurang setiap bulannya dalam rangka untuk pembayaran hal-hal yang berkaita dengan outsourching seperti gaji, lembur dan tunjangan cuti. Prosedur Penarikan dan pemberian biaya operasional adalah sebagai berikut:

a. Setiap melakukan pengeluaran pembiayaan GA Staff dan/atau yang pejabat yang ditunjuk mengajukan transaksi pengeluaran biaya operasional dan membuat rincian anggaran yang akan dikeluarkan untuk keperluan pembiayaaan yang dibutuhkan melalui SPM (surat perinta pembayan)dan dokumen pendukung lainnya..

b. Setelah SPM dan dokumen lainnya disetujui oleh operation Unit Head dan DRM Support maka SPM tersebut diberi nomor biaya dan do catatat dalam buku SPM.

c. Setelah pemberian nomor dan Pencatatan dibuku SPM .maka Dokemen SPM tersebut digandakan sebagai arsip perusahaaan.

d. Document SPM yag digandakan tersbut diarsip dalam orner (map) sesuai dengan nomor dan sesuai dengan nama sandi peneluaran biaya operasional tersebut.

e. SPM dibawa ke teller untuk dicairkan atau ditunaikan dan dana tersebut disimpan kedalam cash box

f. Setiap akhir hari kerja dana sisa yang tersimpan dalam cash box dan setiap awal kerja cash box diambil kembali jika ada pengeluaran biaya yang dibutuhkan oleh karyawan ataupun keutuhan kantor.

g. Setiap hari dana sandi anggaran Operasional dipergunakan untuk memenuhi kebutuhan operasional bank yang relatif kecil seperti pembelian bahan bakar minyak, pembelian alat tulis kantor dan alat tulis cetak, pembelian kebutuhan dapur dan lain-lain yang dipersamakan dengan itu.

Dalam pembiayaan dan pemberian biaya operasional terdapat sistem perencanaan ,pelaksanaan dan pengawasan yaitu perencanaan oleh tim perencanaan anggaran yang ada di kantor pusat, pelaksanaan harian oleh general affair, approval dan otorisator serta pengawasan oleh tim akunting yang juga berada di kantor pusat. Pengawasan pada PT. Bank BTN (persero) kantor Wilayah V Makassar terdiri dari approval ,otorisator sampai dengan internal Control

Nilai nominal pengeluaran biaya operasional tidak ada batasan nominal pengeluaran dari yang terkecil sampai yang terbesar pembayaran diwajibkan dalam bentuk tunai atau transfer kepada rekening pihak ketigauntuk mencegah terjadinya tindakan fraud dan lainlainyang dapat merugikan semua pihak. Jadi Semua transaksi pengeluaran biaya operasional wajib ditransfer ke rekening rekanan pihak keetiga.

Catatan-catatan yang digunakan PT Bank BTN (persero) Kantor Wilayah V Makassar setiap pengeluaran biaya operasional yaitu catatan yang paling entig adalah nominal angka, terbilang tujuan pembayaran sandi yang menjadi beban biaya ,pemotongan pajak serta rekening yang dituju untuk pembayaran. Misalnya:

Pemberian biaya outsourching (gaji karyawan)

Debet : 10.04.01.000.000

Kredit : 10.04.01.000.000 


\section{b. Pembahasan}

\section{Sistem penegeluaran biaya operasional}

Untuk menjalankan suatu usaha diperlukan sumber daya yang harus dikorbankan sebagai nilai pengganti untuk memperoleh keuntungan. Sumber daya ini pada umumnya di nilai dengan satuan uang. Dimana sumber daya yang dipergunakan seringkali disebut dengan biaya. Biaya operasional atau biaya operasi adalah biaya-biaya yang tidak berhubungan langsung dengan produk perusahaan tetapi berkaitan dengan aktivitas operasional perusahaan seharihari.

Secara umum, biaya operasional diartikan sebagai biaya yang terjadi dalam kaitannya dengan operasi yang dilakukan perusahaan dan diukur dalam satuan uang. Dimana biaya operasi sering disebut juga sebagai operational cost atau biaya usaha. Yang termasuk beban operasional adalah semua jenis biaya yang berkaitan langsung dengan kegiatan usaha bank. Beban operasional terdapat dalam laporan laba rugi yang diperoleh dengan menjumlahkan biaya bagi hasil, biaya tenaga kerja, biaya umum administrasi, biaya penyusutan dan penyisihan aktiva produktif, biaya sewa gedung dan inventaris.

Sistem penegeluaran biaya operasional pada PT Bank BTN (persero) Kantor Wilayah V Makassar adalah untuk pengadaan barang dan jasa maka akan dilakukan perbandingan harga berdasarkan penawaran daripihak ketiga, selanjutnya berdasarkan penawaran tersebut akan disepakati dalam bentuk apa misal bulanan, triwulanan, semesteran atau tahunan. Sebagian besar PKS dalam bentuk bulanan sehingga rekanan pihk ketiga akan menagih setiap bulan dan akan dibayarkan oleh petugas.
2. Sistem Penarikan dan pemberian biaya operasional

Dalam pembiayaan dan pemberian biaya operasional terdapat sistem perencanaan ,pelaksanaan dan pengawasan yaitu perencanaan oleh tim perencanaan anggaran yang ada di kantor pusat, pelaksanaan harian oleh general affair, approval dan otorisator serta pengawasan oleh tim akunting yang juga berada di kantor pusat. Pengawasan pada PT. Bank BTN (persero) kantor Wilayah V Makassar terdiri dari approval ,otorisator sampai dengan internal Control. Dalam pembiayaan operasional, penarika dan pemberian biaya terdaat proses perencanaan,pelaksaan dan pegawasan.

\section{a. Perencanaan}

Perencanaan dibuat untuk mengantisipasi segala hal yang akan mengganggu atau menghalangi pencapaian tujuan. Hal ini diatur dalam Surat/memo PT Bank BTN Kantor Wilayah V Makassar yaitu, Dalam rangka efektifitas dan kelancaran operasional kantor pusat dan kantor cabang terkait dengan pembayaran kebutuhan yang sifatnya mendesak dan harus dibayar terlebih dahulu serta untuk menghindari pemakaian uang pribadi pegawai dalam membiayai terlebih dahulu pengeluaran operasional kantor.

b. Pelaksanaan

Pelaksanaan adalah kegiatan yang dilakukan oleh individu atau kelompok dalam mencapai tujuan yang dikehendaki melalui serangkaian proses yang telah direncanakan.

\section{c. Pengawasan}

Pengawasan atau pengendalian diperlukan untuk menjamin bahwa rencana yang ditetapkan telah dilaksanakan sesuai dengan semestinya dan juga menilai apakah menyimpang 
atau sesuai dengan rencana. Dana ini hanya diperuntukan bagi pengeluaranpengeluaran yang jumlahnya relatif kecil. Pengeluaran yang sering dilakukan oleh PT Bank BTN (persero) Kantor Wilayah V Makassar seperti:

$>$ Biaya bahan bakar

$>$ Biaya kebutuhan dapur kantor

$>$ Biaya alat tulis kantor dan alat tulis cetak

Biaya perlengkapan kantor

Biaya peralatan kantor

> Biaya listrik \& telekomunikasi

Serta kebutuhan mendesak lainnya yang jumlahnya relatif kecil

Nilai nominal pengeluaran biaya operasional tidak ada batasan nominal pengeluaran dari yang terkecil sampai yang terbesar pembayaran diwajibkan dalam bentuk tunai atau transfer kepada rekening pihak ketigauntuk mencegah terjadinya tindakan fraud dan lainlainyang dapat merugikan semua pihak. Jadi Semua transaksi pengeluaran biaya operasional wajib ditransfer ke rekening rekanan pihak keetiga.

Catatan-catatan yang digunakan PT Bank BTN (persero) Kantor Wilayah V Makassar setiap pengeluaran biaya operasional yaitu catatan yang paling entig adalah nominal angka, terbilang tujuan pembayaran sandi yang menjadi beban biaya ,pemotongan pajak serta rekening yang dituju untuk pembayaran. Misalnya:

Pemberian biaya outsourching (gaji karyawan)

Debet : 10.04.01.000.000

Kredit : 10.04.01.000.000

\section{PENUTUP}

\section{a. Simpulan}

Berdasarkan hasil penelitian dan analisis data yang telah dilakukan, maka dapat ditarik kesimpulan bahwa:
Sistem penegeluaran biaya operasional pada PT Bank BTN (persero) Kantor Wilayah V Makassar adalah untuk pengadaan barang dan jasa maka akan dilakukan perbandingan harga berdasarkan penawaran daripihak ketiga, selanjutnya berdasarkan penawaran tersebut akan disepakati dalam bentuk apa misal bulanan, triwulanan, semesteran atau tahunan. Sebagian besar (perjanjian Kerja Sama) PKS dalam bentuk bulanan sehingga rekanan pihk ketiga akan menagih setiap bulan dan akan dibayarkan oleh petugas.

\section{b. Saran}

Adapun saran-saran yang dapat dikemukakan dalam penelitian ini yaitu Sandi anggaran biaya operasional untuk PT Bank BTN (persero) Kantor Wilayah V Makassar sebaiknya dinaikkan/ditambah melihat banyaknya pengeluaranpengeluaran yang dilakukan untuk memenuhi kebutuhan kantor Bank BTN (persero) Kantor Wilayah V Makassar dan peneliti berharap bahwa prosedur kerja Bank BTN Kantor Wilayah V Makassar lebih ditingkatkan untuk tercapainya tujuan Bank BTN terutama dibagian Operation Head dan menjadi Bank yang satu-satunya terbesar di Indonesia.

\section{DAFTAR PUSTAKA}

Assauri, sofyan.1999. Manajemen produksi dan Operasi. Jakarta: LPEE Universitas Indonesia

Dendawijaya. lukman. 2005. Manajeman Perbankan.Bogor: Ghalia Indonesia.

Hutahaean. 2015. Pengantar Teknologi Informasi. Jakarta: Bumi Aksara.

Jusuf, jopie. 2008. Analisis Kredit. Yogyakarta : penerbit Andi 
Mulyadi. 2016. Sistem Akuntansi biaya. yogyakarta: UPPSTIM YKPM,2009.

Molan. Benyamin. 2002. Glosarium prentice hall untuk manajeman dan Pemasaran.Jakarta: Prenhalindo.

Siswanto. 2010. Pengantar Manajemen. Jakarta: BumiAksara.

Sujarweni. 2016. Sistem informasi Akuntansi Biaya. Yogyakarta: Gadjah Mada University Press.

Susanto, 2015. Sistem Informasi Akuntansi. Bandung: Lingga Jaya.

Rudianto. 2006. Akuntansi Manajeman. Jakarta: Grasindo.

Debora, RiaMalina. 2015. Sistem Pengendalian Internal Kas Pada PT. Fast food Indonesia, tbk. Tugas Akhir Program Diploma Tiga. Universitas Politeknik Negeri Medan.

Mariani, 2017.Sistem pencairan dan Pengelolaan Dana Kas Kecil Pada PT bank sulselbar kantor Cabang Utama Makassar. Tugas Akhir Program Diploma Tiga. Politeknik Informatika Nasional Makassar.

Republik Indonesia.Undang-Undang No. 13 tahun 1962 tentang asas-asas Ketentuan Bank Pembangunan Daerah.

Republik Indonesia. Undang-Undang No. 10 tahun 1998 tentang perubahan atas Undang-Undang nomor 7 tahun 1992. Status Bank Tabugan Negara. Undang-Undang No.20 tahun1968 tanggal 19-12-1968 tentang perumahan BTN menjadi BNI Unit V.

Ariyanti, Inne. 2015. Pencairan Dana SPM. (Online).http://ineariyanti.blogspot .co.id/2015/03/pencairan-danaspm-di-kpu-kota-bandung.html. Diakses pada tanggal 18 Maret 2019.
Pusat Bahasa Depdiknas. 2016. Kamus Besar Bahasa Indonesia (Edisi Kelima). Jakarta: Balai Pustaka. (Online). http://www.kamuskbbi.com/kamus-besar-bahasaindonesia. Diakses pada tanggal 23 Maret 2019. 